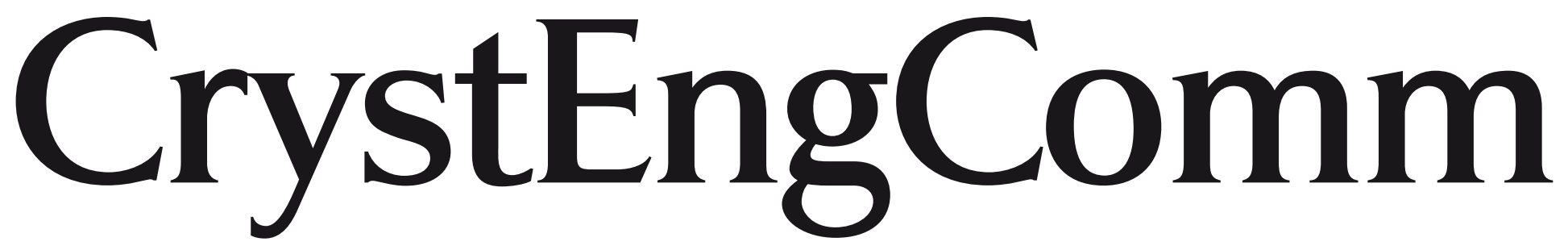

www.rsc.org/crystengcomm

Volume 9| Number 9 | September 2007 | Pages 715-834

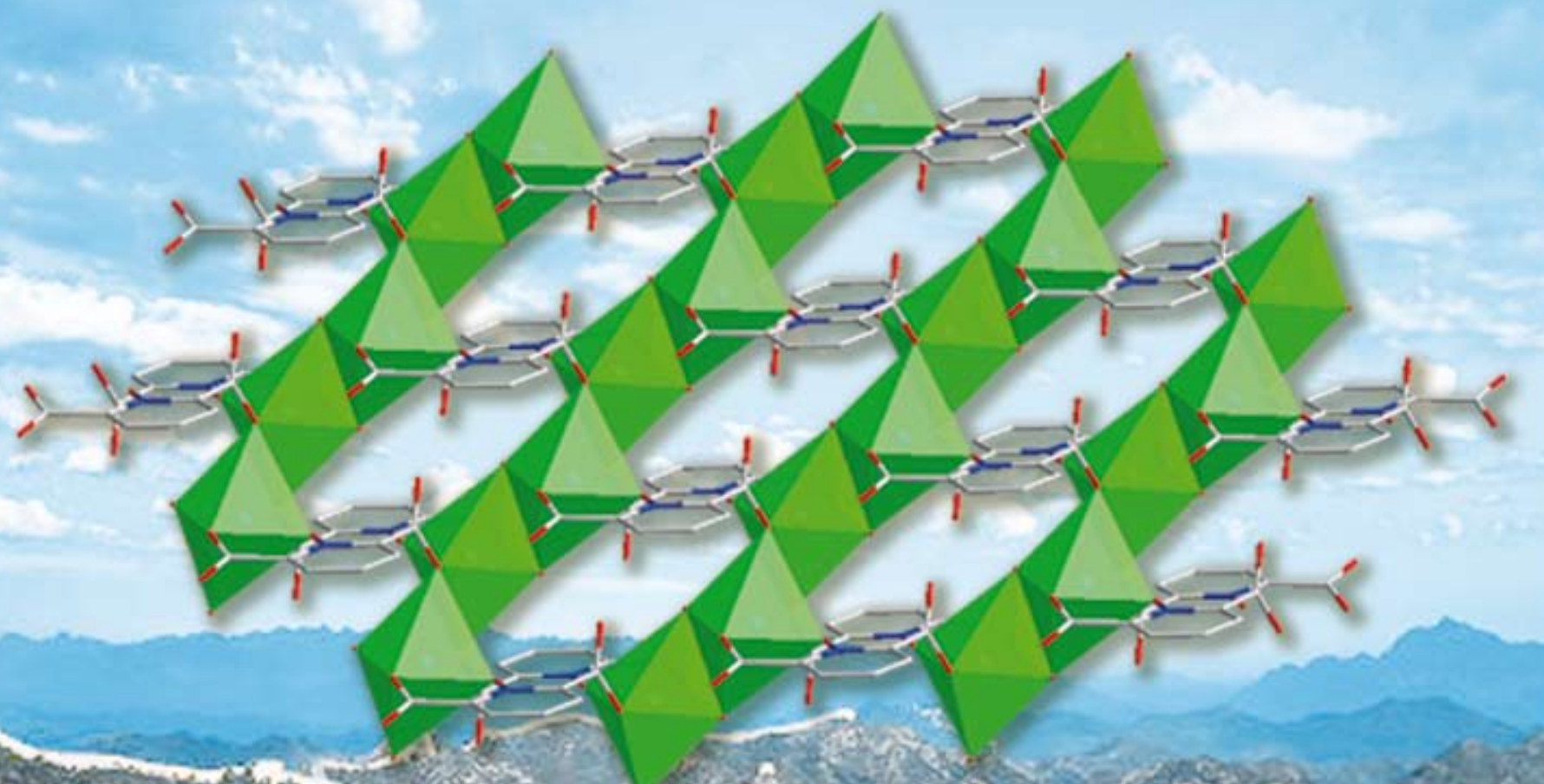

\section{COVER ARTICLE}

Wang et al.

Hydro(solvo)thermal synthesis, structures, luminescence of 2-D zinc(II) and 1-D copper(II) complexes constructed from pyridine-2,6dicarboxylic acid $\mathrm{N}$-oxide

\section{COMMUNICATION}

Fabbiani et al.

Solvent inclusion in the structural voids of form II carbamazepine: single-crystal X-ray diffraction, NMR spectroscopy and Hirshfeld surface analysis 


\title{
Hydro(solvo)thermal synthesis, structures, luminescence of 2-D zinc(II) and 1-D copper(II) complexes constructed from pyridine-2,6-dicarboxylic acid N-oxide and decarboxylation of the ligand
}

\author{
Wei-Ping Wu, ${ }^{a}$ Yao-Yu Wang, ${ }^{* a}$ Ya-Pan Wu, ${ }^{a}$ Jian-Qiang Liu, ${ }^{a}$ Xi-Rui Zeng, ${ }^{b}$ Qi-Zhen Shi ${ }^{a}$ and \\ Shie-Ming Peng ${ }^{c}$
}

Received 29th January 2007, Accepted 26th April 2007

First published as an Advance Article on the web 18th May 2007

DOI: $10.1039 / b 701384 a$

Two new coordination polymers $\left[\mathrm{Zn}(\text { pydco })\left(\mathrm{H}_{2} \mathrm{O}\right)\right]_{n}(\mathbf{1})$ and $\left[\mathrm{Cu}(\text { pyco })_{2}\right]_{n}(\mathbf{2})$ (pydco = pyridine2,6-dicarboxylic acid $\mathrm{N}$-oxide, pyco $=2$-pyridine carboxylic acid $\mathrm{N}$-oxide) have been synthesized by hydro(solvo)thermal reaction of pydco and two transition metal ions in one pot. Complex $\mathbf{1}$ is a 2-D network structure containing double helical chains with a strong emission. Complex 2 displays a 1-D infinite ladder-like chain arrangement. Interestingly, pyco came from the in situ decarboxylation of pydco in the hydrothermal reactions. Through a comparison study in a series of hydro(solvo)thermal reaction of pyridine-2,6-dicarboxylic acid N-oxide and transition metal ions, we confirm that the decarboxylations was catalyzed by $\mathrm{Mn}$ (II) ions.

\section{Introduction}

The design and construction of coordination polymers with unique structural motifs and unique chemical and physical properties has attracted extensive interest in supramolecular chemistry and materials chemistry. ${ }^{1-5}$ In the past decade, plenty of metal-organic hybrids exhibiting fascinating structures $^{6}$ and various properties such as catalysis, ${ }^{7}$ luminescence, ${ }^{8}$ magnetics, ${ }^{9}$ sorption, ${ }^{10}$ ion exchange, ${ }^{11}$ nonlinear optics, ${ }^{12}$ electricity ${ }^{13}$ have been synthesized by chemists. At the same time, versatile synthetic methods and strategy have been developed and applied. ${ }^{14-19}$ Among them, hydro(solvo)thermal in situ ligand synthesis has rapidly developed over the past several years due to its effectiveness, simplicity and environmental friendliness. It has become a forceful and promising approach in crystal engineering of coordination complexes, especially for those not accessible from a direct reaction of metal ions and ligands. ${ }^{20-28}$ More than 10 types of in situ ligand reactions have been reviewed by Zhang and Chen recently, ${ }^{20,28}$ hydrothermal decarboxylation being one of the reactions also observed by several authors. ${ }^{29-32}$ However, the decarboxylation of free carboxylic acids is often difficult, except for some activated acids such as aryl carboxylic acid. Even in this case, it was performed by palladium or nickel catalysts at a high temperature in the gas phase. ${ }^{20,30}$ Herein, we report the synthesis, crystal structures of $\left[\mathrm{Zn} \text { (pydco) }\left(\mathrm{H}_{2} \mathrm{O}\right)\right]_{n}$ (1) and $\left[\mathrm{Cu}(\text { pyco })_{2}\right]_{n}$ (2). Furthermore, through a comparison study in a series of hydro(solvo)thermal reaction of pyridine2,6-dicarboxylic acid $\mathrm{N}$-oxide and transition metal ions, the

${ }^{a}$ Department of Chemistry, Shaanxi Key Laboratory of PhysicoInorganic Chemistry, Northwest University, Xi'an, 710069, P. R. China. E-mail: wyaoyu@nwu.edu.cn; Fax: +86-29-88303798;

Tel: +086-29-88303097

${ }^{b}$ Department of Chemistry, Jinggangshan College, Ji'an, 343009 ,

P. R. China

${ }^{c}$ Department of Chemistry, National Taiwan University, Taipei, Taiwan possible mechanism of the decarboxylation was investigated and confirmed that $\mathrm{Mn}$ (II) ions was important to the decarboxylations of pydco.

Unlike the compound $\left[\mathrm{Zn}(\text { pydco })\left(\mathrm{H}_{2} \mathrm{O}\right)_{2}\right]_{n}$ which possesses a 1-D helical chain-like structure reported by Meng and his coworkers, ${ }^{33}$ complex $\mathbf{1}$ is a $2-\mathrm{D}$ network structure containing double helical chains, while complex $\mathbf{2}$ is a 1-D chain structure. At the same time the emission spectra of complex $\mathbf{1}$ in the solid state at room temperature demonstrate that $\mathbf{1}$ has strong fluorescent emission.

\section{Experimental}

\section{Reagents and physical measurements}

All reagents were commercially available and used without further purification, except pydco which was synthesized according to the literature. ${ }^{34}$ Elemental analyses were determined with a Perkin-Elmer model 240C instrument. Infrared spectra $(\mathrm{KBr})$ pellets was recorded on a Nicolet 170SX FT-IR spectrophotometer in the range of $4000-400 \mathrm{~cm}^{-1}$. Luminescence spectra for the solid samples was recorded with a Hitachi 850 fluorescence spectrophotometer.

\section{Synthesis of $\left[\mathrm{Zn}(\text { pydco })\left(\mathrm{H}_{2} \mathrm{O}\right)\right]_{n}(1)$}

A mixture of $2 \mathrm{Zn}(\mathrm{OH})_{2} \cdot \mathrm{ZnCO}_{3} \cdot \mathrm{H}_{2} \mathrm{O}(0.07 \mathrm{mmol}), \mathrm{CuCO}_{3}$. $\mathrm{Cu}(\mathrm{OH})_{2} \quad(0.13 \mathrm{mmol})$, pydco $(0.50 \mathrm{mmol})$, and $\mathrm{H}_{2} \mathrm{O}$ $(12.00 \mathrm{~mL})$ was placed in a Parr Teflon-lined stainless steel vessel $(25 \mathrm{~mL})$, and then the vessel was sealed and heated at $140{ }^{\circ} \mathrm{C}$ for $2 \mathrm{~d}$. After the mixture was slowly cooled to the room temperature, colorless crystals of $\mathbf{1}$ were obtained (yield: $43 \%$ based on $\mathrm{Zn}$ ). Anal. (\%) calcd for $\mathrm{C}_{7} \mathrm{H}_{5} \mathrm{NO}_{6} \mathrm{Zn}$ : C, 31.78; H, 1.90; N, 5.30; Found: C, 31.97; H, 1.85; N, 5.24. IR (KBr, $\mathrm{cm}^{-1}$ ) for 1: $3264(\mathrm{vs}), 2850(\mathrm{~s}), 2609(\mathrm{~m}), 2488(\mathrm{~s}), 1575$ (s), $1538(\mathrm{~m}), 1397(\mathrm{~m}), 1357(\mathrm{~s}), 1208$ (m), 1180 (m), 1097(vs), 992(w), 934(w), 867(s), 790(m), 734(m), 675(m), 641(w), 581(w), 530(w), 425(w). 


\section{Synthesis of $\left[\mathrm{Cu}\left(\mathrm{pyco}_{2}\right]_{n}\right.$ (2)}

A mixture of $\mathrm{CuCO}_{3} \mathrm{Cu}(\mathrm{OH})_{2} \quad(0.13 \mathrm{mmol}), \mathrm{MnCO}_{3}$ $(0.25 \mathrm{mmol})$, pydco $(0.50 \mathrm{mmol})$, and $\mathrm{H}_{2} \mathrm{O}(2.00 \mathrm{~mL})$, $\mathrm{CH}_{3} \mathrm{CN}(10.00 \mathrm{~mL})$, several dripping of DMF was placed in a Parr Teflon-lined stainless steel vessel $(25 \mathrm{~mL})$, and then the vessel was sealed and heated at $140{ }^{\circ} \mathrm{C}$ for $2 \mathrm{~d}$. After the mixture was slowly cooled to room temperature, several green crystals of 2 were obtained. Anal. (\%) calcd for $\mathrm{C}_{12} \mathrm{H}_{8} \mathrm{~N}_{2} \mathrm{O}_{6} \mathrm{Cu}$ : C, 42.42; H, 2.37; N, 8.25; Found: C, 42.46; H, 2.34; N, 8.31. IR $\left(\mathrm{KBr}, \mathrm{cm}^{-1}\right)$ for 2: $1648(\mathrm{~s}), 1597(\mathrm{~m}), 1476(\mathrm{~s}), 1391(\mathrm{~m})$, 1329(s), 1239 (m), 1180 (m), 1156(vs), 983(w), 930(w), 868(s), 790(m), 729(m), 674(w), 622(w).

\section{Crystallographic data collection and refinement}

Single-crystal X-ray data $\mathbf{1}$ and $\mathbf{2}$ were collected at $296 \mathrm{~K}$ on a Bruker SMART APEX CCD diffractometer using graphitemonochromated Mo $\mathrm{K} \alpha$ radiation $(\lambda=0.71073 \AA)$. Crystal data and details of data collections and refinements for the structures reported are summarized in Table 1. The linear absorption coefficients, scattering factors for the atoms, and the anomalous discussion corrections were taken from International Tables for X-ray Crystallography. ${ }^{35}$ The data integration and reduction were processed with SAINT software. The structures were solved by the direct method using SHELXTL and were refined on $F^{2}$ with SHELXL-97 program package. All non-hydrogen atoms were anisotropically refined. The water $\mathrm{H}$ atoms were located in a different Fourier map and refined with restrained $\mathrm{O}-\mathrm{H}$ bond lengths $(0.85(2) \AA)$ and isotropic displacement parameters $(0.080 \AA)$ in 1 were fixed.

CCDC reference number 631999 for complex 1 and 632000 for complex 2. For crystallographic data in CIF or other electronic format see DOI: 10.1039/b701384a

\section{Results and discussion}

Synthesis chemistry and hydro(solvo)thermal decarboxylation of pydco

In our original attempt to synthesize heteronucleic metalorganic hybrids of pydco by a hydrothermal or a solvothermal method, verdigris and manganese carbonate were sealed into a Teflon-lined reactor. Unexpectedly in situ decarboxylation of the ligand (pydco) was detected which led to a cupric 1-D chain-like polymer as $\left[\mathrm{Cu}(\text { pyco })_{2}\right]_{n}$ (2) as the outcome. According to literature, some decarboxylations catalyzed by $\mathrm{Cu}$ (II) ions have been reported, ${ }^{20,30}$ other experiments have shown that a higher reaction temperature favors decarboxylation of the aromatic carboxyl group under hydrothermal conditions, ${ }^{20,32}$ however there is also some evidence showing that $\mathrm{Cu}(\mathrm{II})$ does not play a catalytic role in the reaction. ${ }^{29}$ So which factor does urge the decarboxylation of pydco in our reaction system? Try to explore the possible factor (such as temperature, cation, reaction time, etc.) by which decarboxylation takes place on the pydco ligand. We designed an experiment with a series of hydrothermal or solvothermal reactions containing foregoing influence factors as shown in Scheme 1 in the attempt to disclose the crucial factor from it. In Scheme 1, we show different cations in these reactions: (a) containing $\mathrm{Cu}$ (II) and $\mathrm{Mn}$ (II) in one pot; (b) containing $\mathrm{Cu}$ (II)
Table 1 Crystallographic data for $\mathbf{1}$ and $\mathbf{2}^{a}$

\begin{tabular}{|c|c|c|}
\hline & 1 & 2 \\
\hline Empirical formula & $\mathrm{C}_{7} \mathrm{H}_{5} \mathrm{NO}_{6} \mathrm{Zn}$ & $\mathrm{C}_{12} \mathrm{H}_{8} \mathrm{~N}_{2} \mathrm{O}_{3} \mathrm{Cu}$ \\
\hline Formula weight & 264.51 & 339.74 \\
\hline Crystal system & Monoclinic & Monoclinic \\
\hline Space group & $P 2_{1} / c$ & $P 2_{1} / c$ \\
\hline alÅ & $5.8976(5)$ & $3.390(7)$ \\
\hline$b / \AA ̊$ & $5.8184(5)$ & $12.590(3)$ \\
\hline$c / \AA ̊$ & $23.7876(9)$ & $12.170(2)$ \\
\hline$\alpha /^{\circ}$ & 90.00 & 90.00 \\
\hline$\beta 1^{\circ}$ & $90.574(0)$ & $94.18(3)$ \\
\hline$\gamma / 1^{\circ}$ & 90.00 & 90.00 \\
\hline$V / \AA^{3}$ & $816.23(2)$ & $518.04(8)$ \\
\hline$Z$ & 4 & 2 \\
\hline$T / \mathrm{K}$ & 296(2) & $296(2)$ \\
\hline$\rho_{\text {calcd }} /$ g.cm ${ }^{-3}$ & 1.364 & 2.178 \\
\hline$\mu / \mathrm{mm}^{-1}$ & 3.018 & 2.145 \\
\hline$F(000)$ & 528 & 342 \\
\hline Reflections collected & 4663 & 4153 \\
\hline Reflections unique & 1806 & 1352 \\
\hline$R_{\text {(int) }}$ & 0.0524 & 0.0257 \\
\hline$R_{1}[I>2 \sigma(I)]$ & 0.0358 & 0.0238 \\
\hline$w R_{2}$ (all data) & 0.0958 & 0.0738 \\
\hline \multicolumn{3}{|c|}{$\left.{ }^{a} R_{1}=\Sigma|| F_{\mathrm{o}}|-| F_{\mathrm{c}} \mid\right) / \Sigma\left|F_{\mathrm{o}}\right| ; w R_{2}=\left[\Sigma w\left(F_{\mathrm{o}}{ }^{2}-F_{\mathrm{c}}{ }^{2}\right)^{2} / \Sigma w\left(F_{\mathrm{o}}{ }^{2}\right)^{2}\right]^{1 / 2}$} \\
\hline
\end{tabular}

and $\mathrm{Zn}$ (II) in one pot as expressed in synthesis part, and (c)-(e) containing only one cation, respectively. In reactions (d) and (e), a temperature of 120 and $140{ }^{\circ} \mathrm{C}$ was used, respectively. The temperature in reactions (b) and (c) is also different. In fact, reactions (b), (d) and (e) also take place during different times, that is $2 \mathrm{~d}$ and $4 \mathrm{~d}$, respectively. Thus the scheme contains twelve reactions.

From those reactions in Scheme 1 we can see that although we did not obtain the crystal structures from reactions (d) and (e), the hydrothermal reaction (b) resulted in the formation of a 2-D coordination polymer of $\left[\mathrm{Zn}(\text { pydco })\left(\mathrm{H}_{2} \mathrm{O}\right)\right]_{n}(\mathbf{1})$, and reaction (c) reported by Meng and coworkers led to a 1-D helical chain-like polymer complex of pydco and $\mathrm{Zn}$ (II) ions. Notably, decarboxylation of pydco did not occur in either reaction when copper salt was present or transition metal ions other than $\mathrm{Cu}$ (II) were used. In order to examine whether the temperature has an influence on the outcome or not, various temperatures were also used. These results indicate that Mn(II) possibly plays a catalytic role in the hydro(solvo)thermal decarboxylation process. To our best knowledge, this reaction is the first example in which elimination of a carboxyl group occurs under hydro(solvo)thermal conditions with $\mathrm{Mn}$ (II) ions as catalyst.

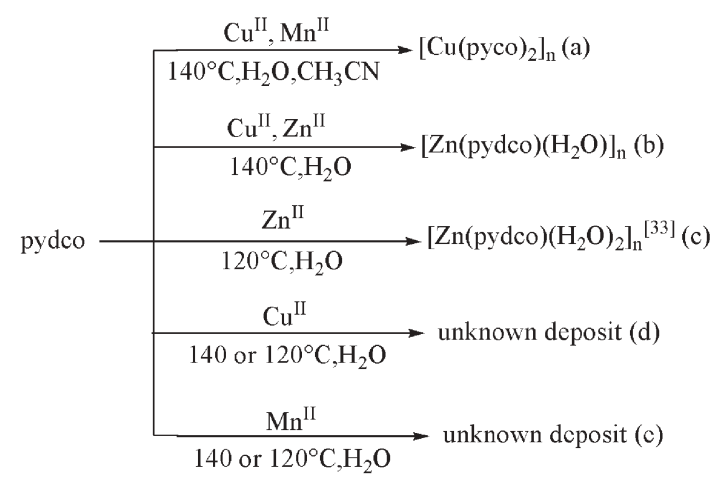

Scheme 1 


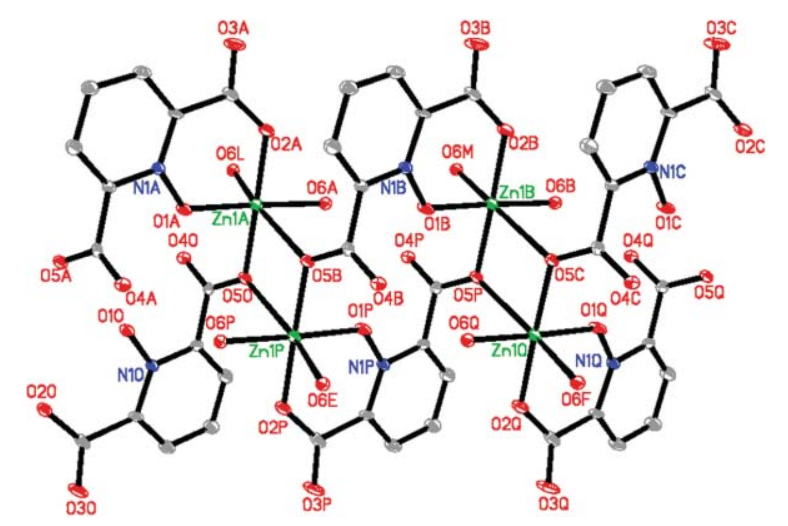

Fig. 1 Coordination environment of the zinc atom and pydco in the [Zn (pydco) $\left.\left(\mathrm{H}_{2} \mathrm{O}\right)\right]_{n}$ (1) showing $25 \%$ probability ellipsoids and the atom-labeling scheme (the bond distances, angles and symmetry codes have been shown in Table 2).

Crystal structures. $\left[\mathrm{Zn}\left(\text { pydco) }\left(\mathrm{H}_{2} \mathrm{O}\right)\right]_{n}(1)\right.$

The structure of compound $\mathbf{1}$ crystallizes in a centrosymmetric space group $P 2_{1} / c$, and the coordination geometry around the zinc(II) center is a slightly distorted octahedron, the equatorial plane of which comprises four oxygen atoms, two from the carboxylate group from different ligands, a $\mathrm{N}$-oxide moiety of pydco anions and a coordinated water molecule; oxygen atoms from the third carboxylate groups and another coordinated water molecule occupy the remaining apical coordination sites, as shown in Fig. 1. The $\mathrm{Zn}-\mathrm{O}$ distances range from 1.889(2) to 2.556(2) $\AA$, with the $\mathrm{O}-\mathrm{Zn}-\mathrm{O}$ bond angles varying from $78.18(9)$ to $176.87(1)^{\circ}$ (Table 2). The axial $\mathrm{Zn}-\mathrm{O}$ distances are obviously longer than those in the equatorial plane. As to the pydco anion, the two carboxylate groups of the ligand are coordinated to the $\mathrm{Zn}$ atom in a monodentate and a single oxygen bridging fashion, respectively, while the $N$-oxide moiety in a monodentate fashion. Both of them are different to the coordination form in $\left[\mathrm{Zn}(\text { pydco })\left(\mathrm{H}_{2} \mathrm{O}\right)_{2}\right]_{n}{ }^{33}$ and $\left[\mathrm{Ag}_{2}\right.$ (pydco) $]_{n}$ that was reported by us earlier. ${ }^{36}$ Unlike the free pydco, the two carboxylate groups are out of the plane of correspondingly linking pyridine rings, with the dihedral angles between them being $c a .16$ and $100^{\circ}$, respectively. The twists of pydco $^{2-}$ in $\mathbf{1}$ are possibly smaller than that in $\left[\mathrm{Zn} \text { (pydco) }\left(\mathrm{H}_{2} \mathrm{O}\right)_{2}\right]_{n}$ and its different coordination environment. The remarkably structural feature of the compound $\mathbf{1}$ is that it possesses a 1-D double helical chain-like motifs along

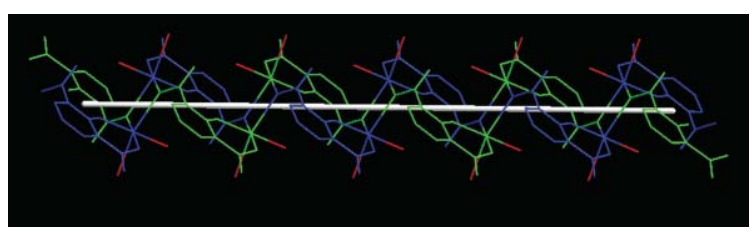

Fig. 2 View of the 1-D double helical chain-like motifs along the $b$-axis in $\mathbf{1}$. Hydrogen atoms have been omitted for clarity.

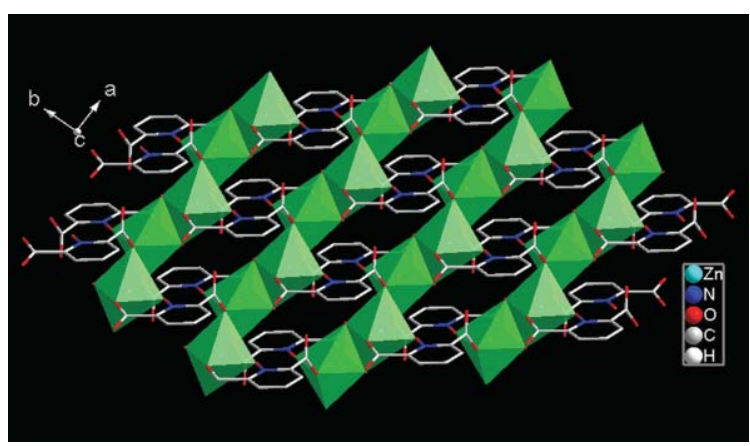

Fig. 3 View of the 2-D network of $\mathbf{1}$ in the $a b$-plane, Hydrogen atoms have been omitted for clarity. Green polyhedrons represent the edgesharing $\mathrm{ZnO6}$ octahedrons in the network.

the $b$-axis (Fig. 2). Furthermore, the helical motifs were linked to a 2-D network by the two coordinated water molecules (Fig. 3). It is worthwhile to point out that in this 2-D coordination polymer, there are quaternary-cyclic intensely intramolecular hydrogen-bonding interactions between coordinated water molecules and carboxylate groups of the ligands

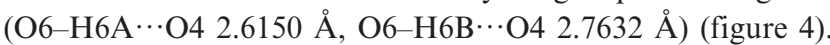
They may be important for intensifying the 2-D network, as the link bonds between double chains are comparatively weak.

\section{$\left[\mathrm{Cu}\left(\mathrm{pyco}_{2}\right)_{n}(\mathbf{2})\right.$}

Complex 2 displays a 1-D infinite ladder-like chain arrangement (Fig. 5). It must be mentioned that in this compound, the $a$-axis unit-cell dimension is 3.3900(7) $\AA$ which is less than the van der Waals diameter for a carbon atom. There are two similar examples in literature reported by D. S. Yufit et al. and A. J. Jacobson et $\mathrm{al}^{37,38}$ The coordination geometry around the copper(II) center is a heavily elongated octahedron, the equatorial plane of which comprises four oxygen atoms from

Table 2 Selected bond distances $(\AA)$ and angle $\left({ }^{\circ}\right)$ for $\mathbf{1}$ and $\mathbf{2}$

\begin{tabular}{|c|c|c|c|c|c|}
\hline \multicolumn{6}{|l|}{ Complex $1^{a}$} \\
\hline $\mathrm{O} 2 \mathrm{~A}-\mathrm{Zn} 1 \mathrm{~A}-\mathrm{O} 1 \mathrm{~A}$ & $93.63(1)$ & $\mathrm{O} 2 \mathrm{~A}-\mathrm{Zn} 1 \mathrm{~A}-\mathrm{O} 5 \mathrm{~B}$ & $105.69(1)$ & $\mathrm{O} 2 \mathrm{~A}-\mathrm{Zn} 1 \mathrm{~A}-\mathrm{O} 6 \mathrm{~A}$ & $89.57(1)$ \\
\hline $\mathrm{O} 6 \mathrm{~A}-\mathrm{Zn} 1 \mathrm{~A}-\mathrm{O} 5 \mathrm{O}$ & $89.58(7)$ & $\mathrm{O} 5 \mathrm{O}-\mathrm{Zn} 1 \mathrm{~A}-\mathrm{O} 5 \mathrm{~B}$ & $78.18(9)$ & O1A-Zn1A-O6A & $176.87(4)$ \\
\hline \multicolumn{6}{|l|}{ Complex $2^{b}$} \\
\hline Cu1-O1A & $1.870(8)$ & $\mathrm{Cu} 1-\mathrm{O} 1 \mathrm{~B}$ & $2.578(3)$ & $\mathrm{Cu} 1-\mathrm{O} 1 \mathrm{AB}$ & $2.578(3)$ \\
\hline $\mathrm{O} 1 \mathrm{AB}-\mathrm{Cu} 1-\mathrm{O} 1$ & $82.02(7)$ & & & & \\
\hline
\end{tabular}




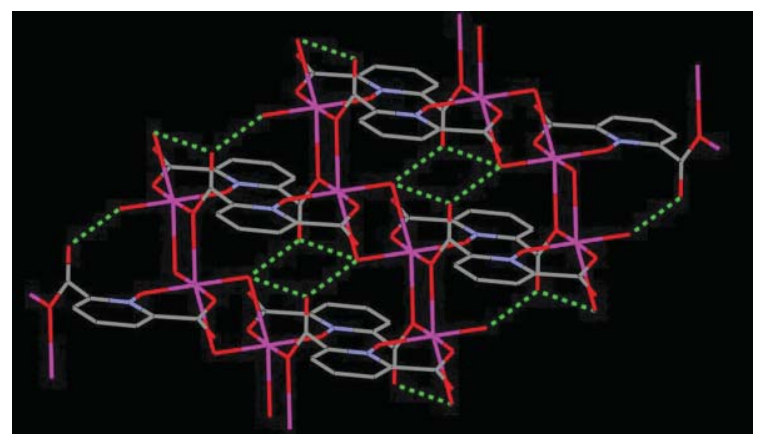

Fig. 4 View of the quaternary cyclic intramolecular hydrogenbonding interactions between coordinated water molecules and carboxylate groups of the ligands in $\mathbf{1}$. Hydrogen atoms have been omitted for clarity.

the carboxylate groups and $N$-oxide moieties of two different pyco anions; the $\mathrm{Cu}-\mathrm{O}$ distances range from $1.870(8)$ to 1.894(8) $\AA$ (Table 2), two $N$-oxide moieties from another ligands occupy the remaining apical coordination sites, the $\mathrm{Cu}-\mathrm{O}$ distances are the same, 2.578(3) $\AA$, which is weak but non-negligible. ${ }^{39-42}$ The elongation of the $\mathrm{Cu}-\mathrm{O}$ bond is ascribed to the John Teller effect. Unlike 1, all of the carboxylate groups of the pyco anions are coordinated to $\mathrm{Cu}$ atoms in a monodentate fashion, while the $N$-oxide moiety is in a bridging fashion coordinated to two $\mathrm{Cu}$ atoms. Interestingly, there are strong aromatic $\pi-\pi$ interactions between the pyridyl units of the intra-chain with a face-toface distance of $c a .3 .390 \AA$, These interactions are probably important to the arrangement of the chain structure.

\section{Photoluminescence properties of 1}

The emission spectrum of complex 1 in the solid state at room temperature is investigated. Excitation at $250 \mathrm{~nm}$ leads to a strong fluorescent emission band at about $395 \mathrm{~nm}$ (Fig. 6). The

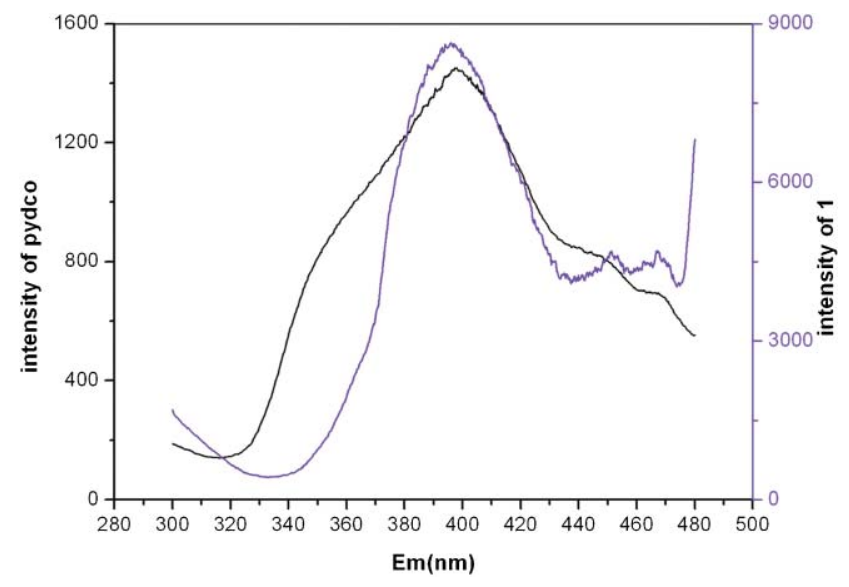

Fig. 6 Fluorescence spectra of complex $1(E x=250 \mathrm{~nm})$ and free pydco $(E x=260 \mathrm{~nm})$ in the solid state at room temperature.

emission can probably be assigned to the intraligand $\left(\pi-\pi^{*}\right)$ fluorescent emission because similar emissions under the same conditions are observed for the free pydco at $398 \mathrm{~nm}\left(\lambda_{\mathrm{Ex}}=\right.$ $260 \mathrm{~nm})$ as we reported before. ${ }^{36}$ It is clear that the coordination bonds significantly improve the luminescence intensity of pydco by enhancing the structural rigidity and reducing the fluorescence quenching effect. ${ }^{33,43,44}$

In summary, we have successfully synthesized two novel coordination polymers based on pyridine-2,6-dicarboxylic acid $\mathrm{N}$-oxide and transition metal ions under hydrothermal conditions, and characterized their single crystal structures. Interestingly, decarboxylation occurred and pyridine-2,6dicarboxylic acid $\mathrm{N}$-oxide was transformed into 2-pyridine carboxylic acid $\mathrm{N}$-oxide in the presence of $\mathrm{Cu}^{2+}$ and $\mathrm{Mn}^{2+}$ ions under the hydrothermal reaction conditions. These results of the comparison study in a series of hydro(solvo)thermal reaction of pyridine-2,6-dicarboxylic acid $\mathrm{N}$-oxide and transition metal ions indicate that $\mathrm{Mn}$ (II) possibly plays a catalytic

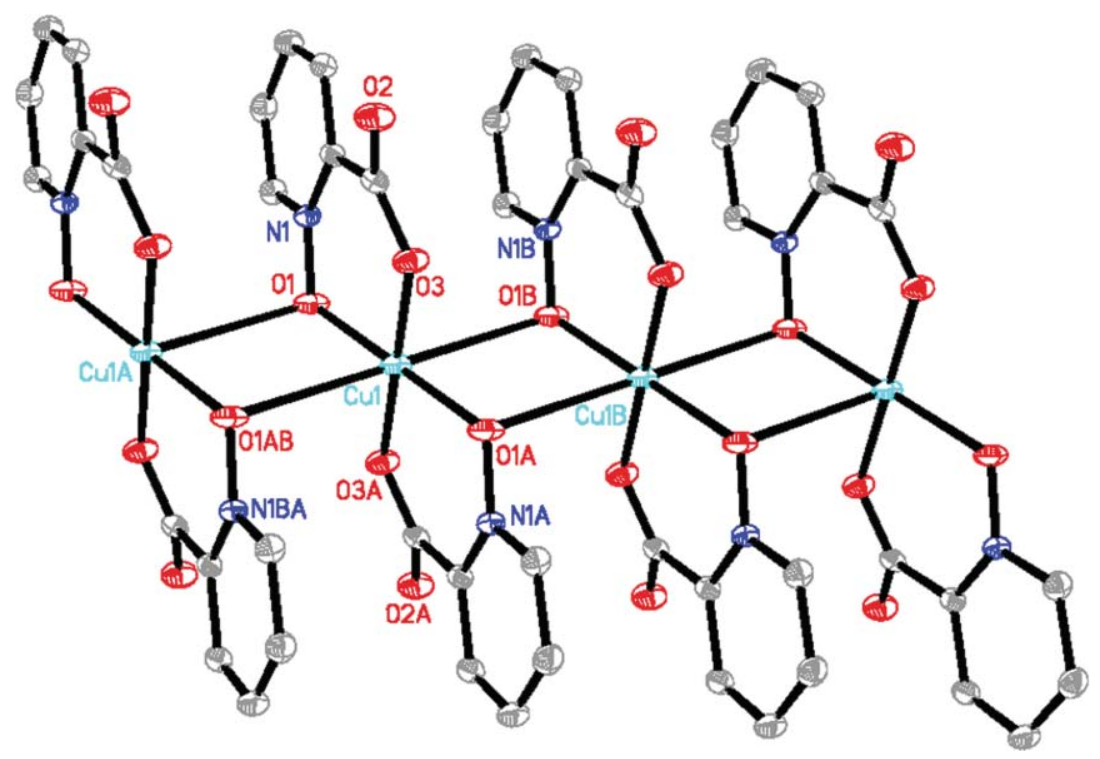

Fig. 5 Structure of the $\left[\mathrm{Cu}(\text { pyco })_{2}\right]_{n}(\mathbf{2})$ extended chain showing $30 \%$ probability ellipsoids and the atom-labeling scheme (A $1+x, y, z$ and $\mathrm{B}-1+$ $x, y, z$, i.e. the chain extends in the $a$-direction. Other symmetry codes have been shown in Table 2). 
role in the hydro(solvo)thermal decarboxylation process. The photoluminescent behavior of $\mathbf{1}$ has been also discussed and $\mathbf{1}$ has a strong luminescence.

\section{Acknowledgements}

This work was supported by the National Natural Science Foundation of China (No. 20471048) and TRAPOYT, and Specialized Research Found for the Doctoral Program of Higher Education (No. 20050697005).

\section{References}

1 (a) J.-P. Zhang and X.-M. Chen, Chem. Commun., 2006, 1689; (b) L. Carlucci, G. Ciani and D. M. Proserpio, Coord. Chem. Rev., 2003, 246, 247; (c) A. Y. Robin and K. M. Fromm, Coord. Chem. Rev., 2006, 250, 2127; (d) X.-J. Luan, X.-H. Cai, Y.-Y. Wang, D.-S. Li, C.-J. Wang, P. Liu, H.-M. Hu, Q.-Z. Shi and S.-M. Peng, Chem.-Eur. J., 2006, 12, 6281.

2 (a) J. Mrozinski, Coord. Chem. Rev., 2005, 249, 2534; (b) M. J. Rosseinsky, Microporous Mesoporous Mater., 2004, 73, 15; (c) J. L. Serrano and T. Sierra, Coord. Chem. Rev., 2003, 242, 73.

3 (a) J. Muller and B. Lippert, Angew. Chem., Int. Ed., 2006, 45, 2503; (b) S. Kitagawa, R. Kitaura and S. Noro, Angew. Chem., Int. Ed., 2004, 43, 2334; (c) J. L. C. Rowsell and O. M. Yaghi, Angew. Chem., Int. Ed., 2005, 44, 4670; (d) X.-L. Wang, C. Qin, E.-B. Wang, Y.-G. Li, Z.-M. Su, L. Xu and L. Carlucci, Angew. Chem., Int. Ed., 2005, 44, 5824; (e) A. C. G. Hotze, B. M. Kariuki and M. J. Hannon, Angew. Chem., Int. Ed., 2006, 45, 4839.

4 (a) G. Fearey, M.-D. Carolene, C. Serre and F. Millange, Acc. Chem. Res., 2005, 38, 217; (b) S. Das, A. Nag, D. Goswami and P. K. Bharadwaj, J. Am. Chem. Soc., 2006, 128, 402; (c) D. T. Puerta, J. A. Lewis and S. M. Cohen, J. Am. Chem. Soc., 2004, 126, 8388.

5 Y. Zhou, M. Hong and X. Wu, Chem. Commun., 2006, 135.

6 (a) X.-J. Luan, X.-H. Cai, Y.-Y. Wang, D.-S. Li, P. Liu, H.-M. Hu, Q.-Z. Shi and S.-M. Peng, Angew. Chem., Int. Ed., 2005, 44, 2; (b) D. J. Hoffart and S. J. Loeb, Angew. Chem., Int. Ed., 2005, 44, 901; (c) C.-D. $\mathrm{Wu}$ and W. Lin, Chem. Commun., 2005, 3673; (d) Q.-R. Fang, G.-S. Zhu, M. Xue, Q.-L. Zhang, J.-Y. Sun, X.-D. Guo, S.-L. Qiu, S.-T. Xu, P. Wang, D.-J. Wang and Y. Wei, Chem.-Eur. J., 2006, 12, 3754; (e) B. Zhao, P. Cheng, Y. Dai, C. Cheng, D.-Z. Liao, S.-P. Yan, Z.-H. Jiang and G.-L. Wang, Angew. Chem., Int. Ed., 2003, 42, 934; $(f)$ Wen-Guan $\mathrm{Lu}$, Cheng-Yong Su, Tong-Bu Lu, Long Jiang and Jia-Mei Chen, J. Am. Chem. Soc., 2006, 128, 34; (g) X.-Q. Lu, Y.-Q. Qiao, J.-R. He, M. Pan, B.-S. Kang and C.-Y. Su, Cryst. Growth Des., 2006, 6, 1910.

7 (a) D. Fiedler, D. H. Leung, R. G. Bergman and K. N. Raymond, Acc. Chem. Res., 2005, 38, 351; (b) W. Tsai, Y.-H. Liu, S.-M. Peng and S.-T. Liu, J. Organomet. Chem., 2005, 690, 415.

8 (a) X.-P. Yang, R. A. Jones, W.-K. Wong, V. Lynch, M. M. Oyec and A. L. Holmes, Chem. Commun., 2006, 1836; (b) J.-P. Zhang, Y.-Y. Lin, X.-C. Huang and X.-M. Chen, J. Am. Chem. Soc., 2006, 128, 5495 .

9 Q. Ye, Y.-M. Song, G.-X. Wang, K. Chen, D.-W. Fu, P. W. H. Chan, J.-S. Zhu, S. D. Huang and R.-G. Xiong, J. Am. Chem. Soc., 2006, 128, 6554.

10 (a) A. J. Fletchera, K. M. Thomasa and M. J. Rosseinsky, J. Solid State Chem., 2005, 178, 2491; (b) L. Pan, B. Parker, X. Huang, D. H. Olson, J.-Y. Lee and J. Li, J. Am. Chem. Soc., 2006, 128,
4180; (c) J. L. C. Rowsell and O. M. Yaghi, J. Am. Chem. Soc., 2006, 128, 1304; (d) M. Dinca, A. F. Yu and J. R. Long, J. Am. Chem. Soc., 2006, 128, 8904.

11 M. Oh and C. A. Mirkin, Angew. Chem., Int. Ed., 2006, 45, 5492.

12 H. Hou, Y. Wei, Y. Song, L. Mi, M. Tang, L. Li and Y. Fan, Angew. Chem., Int. Ed., 2005, 44, 6067.

13 Y.-Z. Tang, X.-F. Huang, Y.-M. Song, P. W. H. Chan and R.-G. Xiong, Inorg. Chem., 2006, 45, 4868.

14 A. Y. Robin and K. M. Fromm, Coord. Chem. Rev., 2006, 250, 2127.

15 P. J. Steel, Acc. Chem. Res., 2005, 38, 243.

16 D. N. Dybtsev, H. Chun and K. Kim, Chem. Commun., 2004, 1594.

17 Z. Lin, D. S. Wragg and R. E. Morris, Chem. Commun., 2006, 2021.

18 J. Y. Lu, Coord. Chem. Rev., 2003, 246, 327.

19 A. D. Burrows, K. Cassar, R. M. W. Friend, M. F. Mahon, S. P. Rigby and J. E. Warren, CrystEngComm, 2005, 7, 548.

20 X.-M. Zhang, Coord. Chem. Rev., 2005, 249, 1201.

21 Q. Ye, Y.-H. Li, Y.-M. Song, X.-F. Huang, R.-G. Xiong and Z. Xue, Inorg. Chem., 2005, 44, 3618.

$22 \mathrm{D} . \mathrm{Li}$ and $\mathrm{T}$. Wu, Inorg. Chem., 2005, 44, 1175.

23 X.-H. Huang, T.-L. Sheng, S.-C. Xiang, R.-B. Fu, S.-M. Hu, Y.-M. Li and X.-T. Wu, Inorg. Chem. Commun., 2006, 9, 1304.

24 R. K. Afshar, K. E. Granados, M. M. Olmstead and P. K. Mascharak, Inorg. Chem. Commun., 2006, 9, 1286.

25 J.-J. Hou and X.-M. Zhang, Cryst. Growth Des., 2006, 6, 1445.

26 J. Lu, D.-Q. Chu, J.-H. Yu, X. Zhang, M.-H. Bi, J.-Q. Xu, X.-Y. Yu and Q.-F. Yang, Inorg. Chim. Acta, 2006, 359, 2495.

27 L. Han, X. Bu, Q. Zhang and P. Feng, Inorg. Chem., 2006, 45, 5736.

28 X.-M. Chen and M.-L. Tong, Acc. Chem. Res., 2007, 40, 162.

29 M. V. Yigit, Y. Wang, B. Moulton and J. C. MacDonald, Cryst. Growth Des., 2006, 6, 829 .

30 Y.-Q. Sun, J. Zhang and G.-Y. Yang, Chem. Commun., 2006, 1947.

31 X.-M. Zhang and R.-Q. Fang, Inorg. Chem., 2005, 44, 3955.

32 M. Li, J. Xiang, L. Yuan, S. Wu, S. Chen and J. Sun, Cryst. Growth Des., 2006, 6, 2036.

33 L.-L. Wen, D.-B. Dang, C.-Y. Duan, Y.-Z. Li, Z.-F. Tian and Q.-J. Meng, Inorg. Chem., 2005, 44, 7161.

34 L. Syper, K. Kloc, J. Mlochowski and Z. Szulc, Synthesis, 1979, 521.

35 A. J. Wilson, International Tables for X-Ray Crystallography, vol. C, Kluwer Academic Publishers, Dordrecht, 1992, Tables 6.1.1.4 (p. 500) and 4.2.6.8 (p. 219).

36 W.-P. Wu, Y.-Y. Wang, C.-J. Wang, Y.-P. Wu, P. Liu and Q.-Z. Shi, Inorg. Chem. Commun., 2006, 9, 645.

37 D. S. Yufit, D. J. Price, J. A. K. Howard, S. O. H. Gutschke, A. K. Powell and P. T. Woodb, Chem. Commun., 1999, 1561.

38 R. P. ClementL, W. B. Davies, K. A. Ford, M. L. H. Green and A. J. Jacobson, Inorg. Chem., 1978, 17, 2754.

39 A. Cingolani, S. Galli, N. Masciocchi, L. Pandolfo, C. Pettinari and A. Sironi, J. Am. Chem. Soc., 2005, 127, 6144.

40 C. Aronica, G. Pilet, G. Chastanet, W. Wernsdorfer, J.-F. Jacquot and D. Luneau, Angew. Chem., Int. Ed., 2006, 45, 4659.

41 G. Arom, J. Ribas, P. Gamez, O. Roubeau, H. Kooijman, A. L. Spek, S. Teat, E. MacLean, S.-E. Helen and J. Reedijk, Chem.-Eur. J., 2004, 10, 6476.

42 G. Ambrosi, M. Formica, V. Fusi, L. Giorgi, A. Guerri, S. Lucarini, M. Micheloni, P. Paoli, P. Rossi and G. Zappia, Inorg. Chem., 2005, 44, 3249.

43 B. Dutta, P. Bag, U. Flo1rke and K. Nag, Inorg. Chem., 2005, 44, 147

44 S. Mizukami, H. Houjou, K. Sugaya, E. Koyama, H. Tokuhisa, T. Sasaki and M. Kanesato, Chem. Mater., 2005, 17, 50. 